\title{
L. D. E. F. Vesey-Fitzgerald
}

Desmond Vesey-Fitzgerald, one of the leading ecologists in Africa, died peacefully in his sleep in Nairobi on 3/4 May 1974. This news will have come as a shock to his many friends all over the world, for he was a great character and had a gift for inspiring affection and respect from people of all ages and backgrounds. With him passes a store of knowledge of the fauna and flora of Africa which will be hard to replace.

Starting as an entomologist, Vesey's long and varied career took him to the far corners of three continents-anywhere unusual and untrod, it was high odds that he had been there-and his interests broadened over the years to embrace most forms of natural life, as shown by his numerous scientific papers on mammals, birds, reptiles, insects and plants. By 1964, when he joined the Tanzania National Parks as the Ecologist for the northern parks, he had become absorbed in the study of wildlife ecology and he settled down happily to unravel the secrets of three very different areas-the Arusha, Lake Manyara and Tarangire National Parks. In doing so, the catholicity of his knowledge and experience made his perception of ecological processes seem almost intuitive-especially, perhaps, to scientists new to Africa who sometimes felt that his methods were more qualitative than quantitative. However, as one of them remarked recently, 'the trouble of working in East Africa, is that when one has a bright idea, Vesey has usually had it first'. He was devoid of professional jealousy, shared his ideas freely with others and maintained a remarkably high rate of publication. And, of course, he did quantify-although more selectively than most; indeed he was especially proud of his success in having trained his team of Tanzanian assistants to sample vegetational communities with a high degree of reliability for later processing by a computer. As a result of his work, the three National Parks are now documented and described, and the framework for their management set out. The last ten years were among the most productive of his life.

Always excellent company, Vesey loved to take friends round his parks and to share his knowledge and ideas with them. At home, his little house overlooking the Momela Lakes was seldom without guests and he was the most hospitable of men. He liked talking and took pleasure in a contentious evening when he could give full rein to his Irish fecundity of expression. He loved a quirky phrase or a coined word. Like others of his countrymen, he was not unhappy with a grouse, worrying away at it with relish like a dog with a bone. Never pompous, he mixed easily with the young. Many of his guests will remember having woken after a late night of good talk to be revived by the spectacle of Kilimanjaro and Meru towering above them in the clear African sky-with Vesey already in his office.

He was a most unusual person and his death, like the crash of a fine old cedar in his beloved forest on Mount Meru, leaves a gap in the canopy to mark where once he stood. For his colleagues in Tanzania, Momela will never be quite the same again.

JOHN OWEN 